46 (1) | 2017

La orfebrería en los Andes en la época inca (siglos XV$\mathrm{XVI})$

\title{
Oro, riquezas, recursos y poderes andinos en el
} Tawantinsuyu

Jean-François Bouchard

\section{CpenEdition}

\section{Journals}

Edición electrónica

URL: http://journals.openedition.org/bifea/8322

DOI: $10.4000 /$ bifea.8322

ISSN: 2076-5827

\section{Editor}

Institut Français d'Études Andines

Edición impresa

Fecha de publicación: 1 abril 2017

Paginación: 5-8

ISSN: 0303-7495

Referencia electrónica

Jean-François Bouchard, « Oro, riquezas, recursos y poderes andinos en el Tawantinsuyu », Bulletin de I'Institut français d'études andines [En línea], 46 (1) | 2017, Publicado el 08 abril 2017, consultado el 05 noviembre 2020. URL : http://journals.openedition.org/bifea/8322 ; DOI : https://doi.org/10.4000/ bifea.8322

\section{(c)}

Les contenus du Bulletin de l'Institut français d'études andines sont mis à disposition selon les termes de la licence Creative Commons Attribution - Pas d'Utilisation Commerciale - Pas de Modification 4.0 International. 


\title{
Oro, riquezas, recursos y poderes andinos en el Tawantinsuyu
}

\author{
Jean-François Bouchard*
}

Los Andes centrales tienen un largo pasado de actividades metalúrgicas y orfebres sobresalientes. El oro, la plata, el cobre y dos variedades de bronce (arsenical y estañífero) fueron utilizados para manufacturar objetos utilitarios o bien adornos y elementos distintivos para las élites. Las culturas indígenas prehispánicas nunca desarrollaron una metalurgia del hierro.

Desde la época Chavín, e incluso antes, hubo producción orfebre. Alrededor de 1500 a. C. en Waywaka (Andahuaylas, Perú) hay ejemplos de pequeñas láminas de oro trabajado, así como hay ejemplos de cuentas de oro alrededor de 2000 a. C. en el sitio de Jiskairumoko (Puno, Perú). Antes del Imperio inca, la costa norte del Perú fue sin duda la región más activa para la orfebrería y su papel fue de gran importancia durante el Tawantinsuyu (1450-1532 d. C.), cuando los incas dominaron a las poblaciones de este territorio. Existen referencias sobre el traslado de orfebres chimús desde la costa norte hacia la región de Cuzco donde aportaron sus conocimientos y su destreza a la elaboración de la orfebrería imperial.

Debido a su presencia visible en los palacios imperiales y templos religiosos, la producción orfebre fue saqueada y gran parte de ella es desconocida por la arqueología. Se considera como uno de los ejemplos mayores de la destrucción del patrimonio cultural andino. Es un caso paradójico que la orfebrería vista en el Perú por los españoles del siglo XVI haya desaparecido, mientras que los objetos elaborados por las culturas andinas prehispánicas se mantuvieron protegidas en las tumbas y las ruinas indígenas. 
Debemos tomar en cuenta la tecnología utilizada para obtener las materias primas. Muchos factores debieron jugar un papel determinante. El principal fue la dificultad para cavar socavones seguros con herramientas poco adaptadas, en terrenos muy amenazados por numerosos temblores; a esto se suma la creencia que el mundo de abajo no correspondía a la actividad humana sino a fuerzas no terrestres. Luego, para tratar el mineral y después elaborar el objeto era necesario obtener un alto y prolongado grado de calor con combustibles tradicionales: leña y carbón de madera esencialmente, pues el carbón mineral no parece haberse empleado debido a su extracción dificultosa en las vetas y minas. Si bien es probable que los Andes prehispánicos tuviesen más recursos madereros que hoy en día, hay que recordar que la mayor parte debía ser utilizada para diversos usos domésticos o para la producción cerámica.

Por lo tanto, debido a las reducidas fuentes de combustibles, el trabajo de los metales fue relativamente limitado y poco productivo en cuanto a cantidad de producción de materias primas. Las reproducciones de las wayras utilizadas para fundir metal en las fuentes coloniales muestran que no eran de gran tamaño; además los fogones abiertos quedaban a un nivel casi doméstico, sin tener un tamaño comparable a los grandes talleres de fundición conocidos en otros continentes. Los pocos datos que tenemos ilustran una producción orfebre de pequeñas cantidades.

En los siglos anteriores al Tawantinsuyu, la región donde nació el Imperio inca no presenta muchas evidencias de una metalurgia desarrollada. Sin embargo, existen varias fuentes de materia prima no muy lejanas, especialmente en la parte oriental del imperio o Antisuyo. Varios trabajos han subrayado la existencia de placeres y minas auríferas en el piedemonte oriental. El famoso sitio Choquequirao, cuyo nombre significaría la cuna del oro, nos indica el papel importante de la minería aurífera en esta región. De hecho, el territorio en las cercanías de Cuzco pasó directamente a manos de los soberanos y luego de sus panaqas, creándose una región de «propiedades imperiales», algo muy contrario al sistema andino de propiedad colectiva de las tierras indígenas.

Un hecho característico del Imperio inca fue su capacidad de concentrar en manos del poder político una gran cantidad de materias primas necesarias para elaborar bienes y productos de lujo, en beneficio de los poderes del Estado, de la religión y de las élites dirigentes (incas y no incas). Los estudios realizados sobre la economía inca y su capacidad de controlar la producción muestran que los incas tuvieron un control muy eficiente de las materias primas de primera necesidad. Pero también tenían las materias primas de lujo y de la elaboración de productos manufacturados a partir de estas. También supieron obtener una mano de obra excelente, tanto para las tareas «ordinarias», como para los trabajos mucho más elaborados desde el punto de vista tecnológico. De tal modo que los mejores tejidos, la mejor arquitectura y desde luego las más finas obras de orfebrería constituyeron los indicadores visibles del poder imperial, que superaba a los más ricos señoríos preíncas y constituyó el ápex de las civilizaciones andinas. 
En otros casos, sin embargo, los señores étnicos no incas pudieron seguir controlando la producción pero tuvieron que dar cuenta de ella y tributar, lo que constituye otra forma de comerciar la producción. Es muy probable que por parte de los incas existieran muchas variaciones en el manejo de los recursos de las regiones integradas al imperio. Pudieron existir casos de puro «extractivismo»en ciertos territorios anexados y un modo menos «colonizador» que dejaba a algunos grupos más favorecidos una mayor autonomía en la administración de sus recursos. Como en todo imperio grande y amplio, no podía existir uniformidad en la forma de establecer relaciones interétnicas; podemos ver que el trato que se daba, por ejemplo, a las poblaciones de la costa norte peruana fue muy distinto del que se dio a las poblaciones de la sierra, tal vez más cercanas a la cultura cuzqueña. Los incas también se apoderaron de una gran fuerza de trabajo a través de la mit'a que cada adulto tenía que ofrecer al sistema político dominante a cambio de su «integración» al imperio, obteniendo en cambio algunas otras ventajas.

Por otra parte, nos parece muy probable que los incas de la época expansionista del imperio, a pesar de que respetaron por lo general las tradiciones preíncas, hayan empezado a modificar a nivel local la regla de la propiedad privada de las tierras. Las tierras andinas correspondían y pertenecían a los grupos étnicos y no a individuos específicos. Pero en el caso de estas regiones tan ricas, y posiblemente poco habitadas después de las conquistas incas, podemos sugerir que la posibilidad de obtener bienes tan valorizados (metales y productos de lujo como la coca) Ilevaron al poder imperial a tomar como una propiedad «privada» lo que utilizara directamente como una fuente de grandes ingresos, sin perjudicar a muchos pueblos importantes. La privatización de las grandes riquezas estatales por parte de las panaqas jugaría un papel importante en la debilitación progresiva del poder imperial.

En ningún momento parece que las clases populares del Imperio inca hayan podido poseer estos objetos y lo mismo se observa en los períodos anteriores. La producción orfebre fue muy controlada, como también lo fue su distribución. A lo largo de los siglos, la repartición tradicional de los bienes de lujo no cambió en nada pues siempre fue destinada a las élites dirigentes, quedando inaccesibles para las clases populares. Aun durante la hegemonía de Chavín, que fue la primera época andina de producción orfebre, es probable que las élites se reservaran el acceso a estos productos, sea para su uso personal o para un uso cultural y religioso. Es decir que se materializaba en la orfebrería andina la potencia de las elites prehispánicas y que se expresaba la veneración al poder de las divinidades, puesto que las élites y las divinidades fueron los principales (o los únicos) seres que podían poseer estas riquezas orfebres. Por lo tanto se trata de una muy pequeña parte del mundo andino en comparación con las numerosas clases populares que solamente podían contemplar estas joyas y obras de arte orfebre. Muy probablemente debemos ver esta peculiaridad como un límite tecnológico que mantuvo durante varios milenios a la artesanía andina en la producción de objetos manufacturados en madera, piedra pulida y, por supuesto en cerámica para la vajilla y el arte plástico. Desde luego, la orfebrería andina fue vista por los 
conquistadores principalmente como una fuente de materia prima para obtener lingotes y monedas. Así los principales tesoros visibles fueron destruidos sin tomar en cuenta su valor estético o tecnológico. De hecho, debemos valorizar lo poco que pudo ser rescatado y desarrollar todas las técnicas no destructivas para su estudio. 